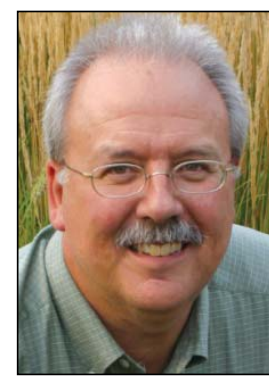

\author{
Metrics FROM the FIELD \\ Blending insights from research with insights from practice \\ Ken Meter
}

\title{
Local data is endangered
}

Published online March 7, 2014

Citation: Meter, K. (2014). Local data is endangered. Journal of Agriculture, Food Systems, and Community Development, 4(2), 7-8. http://dx.doi.org/10.5304/jafscd.2014.042.010

Copyright (C) 2014 by New Leaf Associates, Inc.

$\mathrm{O}$ ne of the quiet impacts of the interruption of federal services in the U.S. - both the ongoing sequestration and the fall 2013 shutdown - was a tragic loss of local-level economic data. This critically threatens our ability to measure the success of community-based foods initiatives.

The Bureau of Economic Analysis (BEA), a unit of the U.S. Department of Commerce, has enjoyed a deservedly solid reputation for publishing impartial data sets. Its Local Area Personal

Ken Meter, president of Crossroads Resource Center, is one of the most experienced food system analysts in the U.S., having produced 97 regional and state foodsystem assessments in 32 states, all focused on local farm and food economies. He directed the US $\$ 9.8$ million "Making Small Farms Big Business" investment plan commissioned by the state of South Carolina in 2013. Meter has also worked with several food banks nationally to bring an economic perspective to their capacity-building work, and recently completed a national study of the economic and social-network impacts of institutional food purchasing with the Illinois Public Health Institute.
Income Statistics (LAPI), in particular, have offered essential measures of local economic activity. Few nations have comparable data.

Yet on November 21, 2013, BEA (2013b) announced that it had suspended publication of several critical local data sets. No longer will BEA report detailed data on farm income and expenses for counties across the U.S. It has stopped reporting transfer payments (such as SNAP benefits) at the county level. BEA will no longer publish local area employment data by industry, nor detailed local summaries of employee compensation or earnings. Gone are its compilations of data covering BEA economic areas (regions defined by economic trade rather than strictly political boundaries). The BEA has also eliminated its Regional Input-Output Modeling System (RIMS II) product - an essential tool for gauging economic impacts of local development plans.

BEA understands the critical importance of its own data. In its press release announcing the cuts, BEA stated, "LAPI [data] constitutes [sic] the only source for county and metropolitan area personal income statistics and are building blocks for other 
regional economic statistics" (BEA, 2013a, p. 1). Luckily BEA's exceptionally user-friendly, interactive website persists, allowing researchers and advocates continued access to many state-level data sets.

As we wait for the publication of county-level data from the 2012 Census of Agriculture - also delayed by the fall shutdown it becomes clear that local data itself is endangered in a political era that questions every possible public expenditure.

Indeed, the field of economics moved away from locallevel data several decades ago. The penetration of the global economy was so complete, many argued, that only nationallevel or multination data could offer meaningful tallies. Money flowed so freely across county lines that there was little to be gained by attributing economic activity to place, this worldview asserted.

BEA was one government agency that expressed a counterpoint to that assertion. Recognizing that most economic development occurs in specific places, often shaped by local incentives, BEA doggedly provided municipal decision-makers with the tools to understand local income trends. For me, the economic data covering farm income and SNAP have served as essential tools. Data on farm income and expenses have been one of the few detailed ways to show the workings of the overall economy at the local level.

In recent years, of course, there has been an outpouring of public interest in local economies. This is integral to community-based foods initiatives. Ironically, just as local leaders ask for solid measures of local economic impacts, the essential data that could provide them has been electronically erased.

This has profound consequences for commu- nities across the U.S. Since our choices of what to measure sometimes define which issues we address, the opportunity to shape local policy is likely to further diminish. If local data is not readily available, many national policy-makers will be tempted to think that local issues can easily be overlooked.

Ironically, ideologues who reject a federal role in favor of greater local authority have undermined the possibility of exercising local authority and a political calculation at the White House has reinforced their worldview.

When I contacted the BEA to point out that its funding decision had dire consequences for both my professional practice and for local economic planning across the U.S., the official who responded expressed hope that funding would be restored in a saner political climate. Perhaps if researchers take it upon themselves to speak out, both to Congress and to BEA itself, these essential data sets will be restored.

\section{References}
Bureau of Economic Analysis. (series). Local Area Personal Income Statistics. http://www.bea.gov/regional/ index.htm
Bureau of Economic Analysis. (2013a, June 19). Impact of sequestration reductions on the availability and quality of data from the Burean of Economic Analysis [Media release]. U.S. Department of Commerce. Retrieved from http://www.bea.gov/about/pdf/bea fy2013 budget impact.pdf
Bureau of Economic Analysis. (2013b, November 21). Impact of sequestration and reduced FY 2013 funding levels on Local Area Personal Income (LAPI). U.S. Department of Commerce, BEA. Retrieved Feb. 2014 from http://www.bea.gov/regional/docs/ImpactBudgetAct $\underline{\text { LAPI.cfm }}$

